\title{
Extradural infections of the spine
}

\author{
$\mathrm{J}_{\text {Klekamp*,1 }}$ and M Samii ${ }^{1}$ \\ ${ }^{1}$ Medical School of Hannover, Neurosurgical Clinic, Nordstadt Hospital, Hannover, Germany
}

Objectives: We have observed a recent increase in the incidence of spinal extradural infections. To determine postoperative outcome and prognosis we have undertaken a retrospective study on patients with spinal extradural abscesses between 1978 and 1996 treated in the Department of Neurosurgery at the Nordstadt Hospital in Hannover, Germany.

Methods: Case records, outpatient files, operation notes, neuroradiological examinations and pathological reports were analysed. Neurological function was documented using a score system for each symptom.

Results: Twenty-two patients underwent 24 operations during the study period. Staphylococcus aureus was the organism most commonly isolated. Patients presented after a mean history of $1.8 \pm 2.6$ months with acute development of severe para- or tetraparesis and were followed up for an average period of $6 \pm 7$ months.

Two groups were distinguished. One group was characterized by epidural collections of pus (14 patients). Two patients in this group were not operated due to their moribund state and died from uncontrollable septicemia. Two of the remaining 12 operated patients died within 30 days after surgery due to generalized septicemia or other medical problems unrelated to the spinal involvement. Of the ten surviving patients, five sustained major neurological deficits, whereas the remaining five patients made an incomplete recovery. The second group consisted of eight patients in a significantly better pre-operative health condition in whom granulomatous material was obtained during the operation and the outcome was considerably better. No patient in this group died. Six patients recovered with no or mild neurological deficits.

Conclusion: Spinal extradural infections require immediate surgical intervention. Neurological outcome depends on the pre-operative neurological status. Survival is determined by the general health condition of the patient.

Keywords: spine; inflammatory disease; spinal abscess

\section{Introduction}

Spontaneous extradural infections of the spine may be caused by haematogenous spread or local extension from another inflammatory process, such as osteomyelitis or spondylodiscitis of the spine. ${ }^{1-6}$ Once the epidural space of the spinal canal is reached, symptoms may progress rapidly to complete paraplegia.

Since the advent of antibiotics and better health standards the incidence of this disease and the high mortality had declined in the past. Surprisingly to us, a considerable number of patients with spontaneous epidural infections have been admitted to our department within the last few years suggesting that the overall incidence may be rising again. ${ }^{7-10}$ We have conducted this retrospective study to document the clinical course and outcome for these patients.

*Correspondence: J Klekamp, M.D., Medical School of Hannover, Neurosurgical Clinic, Nordstadt Hospital, Haltenhoffstr. 41, 30167 Hannover, Germany

\section{Materials and methods}

We have studied retrospectively all patients with spontaneous spinal epidural infections between 1977 and 1996 who were treated in the Department of Neurosurgery at the Nordstadt Hospital in Hannover, Germany. During this period we encountered 22 patients with this diagnosis. They underwent a total of 24 operations. Two patients were not operated on due to their moribund state at the time of admission. The remainder were operated on as soon as the diagnosis was made. We encountered eight cervical, three cervicothoracic, three thoracic, one thoracolumbar and seven lumbar inflammatory processes.

One patient with an extensive cervicothoracic abscess requried two operations as the full extent of the spinal involvement was not apparent on the preoperative computer tomography (CT) and was detected on the postoperative magnetic resonance scan (MRI). Another patient with a thoracic granuloma underwent four surgical procedures within 3 years due to local recurrences. 
Case records, operation reports, follow-up information, and neuroradiological findings were evaluated. The clinical course was documented using the Karnofsky score $^{11}$ and a score system for each symptom (Table 1). ${ }^{12}$ In general, scores between three and five describe satisfactory levels of function and scores between two and 0 indicate unsatisfactory or incapacitated function. Only the most severely affected limb was analyzed in this manner. The general health status before treatment was graded as follows:

(5) no medical problem

(4) minor medical problem, no medication necessary

(3) medical problem, manageable with drugs, no hospitalization

(2) significant medical problem requiring hospitalization

(1) moribund state

Pre-operative imaging consisted of plain X-rays and computer tomography (CT) with bone windows of the affected spinal segment and a myelogram with postmyelographic CT before MRI became available. Since then, we perform myelography only in cases with multilevel involvement to determine those spinal segments with spinal cord compression. For most patients MRI with and without gadolinium was sufficient and was considered as the imaging modality of choice. CT with bone windows may be added to demonstrate the bony destruction more adequately.

The surgical approach depended on the extent of bony involvement. In patients with osteomyelitis or spondylodiscitis, a ventral approach was chosen to ensure adequate debridement of the spinal canal and affected vertebrae with removal of the discs, followed by fusion if required. If vertebrae and intervertebral disc spaces were unaffected, a posterior approach was chosen.

According to intra-operative evidence of a purulent collection and histological examinations, abscesses and granulomas were distinguished. Abscesses were characterized by purulent collections surrounded by an inflammatory infiltrate of lymphocytes and plasma cells. With granulomas, no pus was seen during surgery but granulation tissue of varying consistency, sometimes poorly distinguishable from surrounding soft tissues. Histologically, there was no evidence of a specific inflammatory reaction, such as Langhans cells or epitheloid cells, but an inflammatory infiltrate of granulocytes with signs of a more chronic inflammatory process, such as scar formation.

Adjunctive therapy consisted of intravenous antibiotics according to resistance testing. If an organism could not be isolated, a combination of three antibiotics (cephalosporin, aminoglycoside and metronidazol) was given. The antibiotic medication was sustained for a minimum of 4 weeks without bony involvement and 8 weeks with osteomyelitis.

Postoperatively, every patient received plain X-rays, and either CT with bone window and intravenous contrast or an MRI. Further scans were performed if clinical symptoms worsened again. Clinical examinations were performed before discharge and after 3 months for all surviving patients. Additional follow-up information was obtained by further outpatient examinations, questionnaires, or through the referring physician. The average follow-up period was $6 \pm 8$ months.

Means are presented plus/minus the standard deviation. For statistical analyses Student's $t$-tests for paired or unpaired variables were used provided the Komolgorov-Smirnov test indicated normal data distribution. A multiple regression analysis was performed to determine those factors which predict postoperative survival. For analysis of survival rates the Kaplan-Meier method was used. ${ }^{13} \mathrm{~A}$ difference was considered significant if a $P$-value of 0.05 was reached.

\section{Results}

\section{Pre-operative characteristics}

Table 2 summarizes the clinical data. For the majority of patients, local pain was the first clinical symptom noted. Most patients presented acutely with a rapidly progressing neurological deficit which had proceeded to complete paraplegia in three cases of spinal abscesses.

Table 1 Clinical scoring system

\begin{tabular}{|c|c|c|c|c|c|}
\hline Score & $\begin{array}{l}\text { Sensory deficits, } \\
\text { pain, dysesthesias }\end{array}$ & Motor weakness & Gait ataxia & Bladder function & Bowel function \\
\hline 5 & No symptom & Full power & Normal & Normal & Normal \\
\hline 4 & Present, not significant & $\begin{array}{l}\text { Movement against } \\
\text { resistance }\end{array}$ & Unsteady, no aid & $\begin{array}{l}\text { Slight, disturbances, } \\
\text { no catheter }\end{array}$ & $\begin{array}{l}\text { Slight, disturbances, } \\
\text { full control }\end{array}$ \\
\hline 3 & $\begin{array}{l}\text { Significant, function not } \\
\text { restricted }\end{array}$ & $\begin{array}{l}\text { Movement against } \\
\text { gravity }\end{array}$ & Mobile with aid & $\begin{array}{l}\text { Residual, no } \\
\text { catheter }\end{array}$ & $\begin{array}{l}\text { Laxatives, full } \\
\text { control }\end{array}$ \\
\hline 2 & Some restriction of function & $\begin{array}{l}\text { Movement without } \\
\text { gravity }\end{array}$ & Few steps with aid & Sometimes catheter & $\begin{array}{l}\text { Sometimes loss of } \\
\text { control }\end{array}$ \\
\hline 1 & Severe restriction of function & $\begin{array}{l}\text { Contraction without } \\
\text { movement }\end{array}$ & Standing with aid & Often catheter & Often loss of control \\
\hline 0 & Incapacitation of function & Plegia & Wheel chair & Permanent catheter & No control \\
\hline
\end{tabular}


Table 2 Clinical data

\begin{tabular}{|c|c|c|c|c|c|c|c|c|c|c|c|c|}
\hline Number & $\begin{array}{l}\text { Age } \\
\text { years }\end{array}$ & Sex & Level & History & Fever & $\begin{array}{l}\text { Leuco } \\
\text { cytosis }\end{array}$ & $E S R$ & $\begin{array}{l}\text { Blood } \\
\text { culture }\end{array}$ & Bact. & $\begin{array}{l}\text { Risk } \\
\text { factors }\end{array}$ & $\begin{array}{l}\text { Preop. } \\
\text { status }\end{array}$ & Outcome \\
\hline \multicolumn{13}{|c|}{ Granuloma } \\
\hline S. F. & $55 \mathrm{y}$ & $\mathrm{m}$ & $\mathrm{C} 2-5$ & 8 weeks & neg. & + & 53 & neg. & Ps. Aer. & $\begin{array}{l}\text { deep venous } \\
\text { thrombosis }\end{array}$ & $\begin{array}{l}\text { mild } \\
\text { deficit }\end{array}$ & imp. amb. \\
\hline F. K. & $43 y$ & $\mathrm{~m}$ & L4-5 & 4 weeks & neg. & + & 61 & neg. & neg. & $\begin{array}{l}\text { diabetes, } \\
\text { alcohol, } \\
\text { pancreat., } \\
\text { hepatitis, } \\
\text { GI-ulcer }\end{array}$ & $\begin{array}{l}\text { pain no } \\
\text { def. }\end{array}$ & imp. amb. \\
\hline L. C. & $53 y$ & $\mathrm{f}$ & T5-7 & 1 week & + & + & 93 & neg. & St. Aur. & neg. & $\begin{array}{l}\text { severe } \\
\text { deficit }\end{array}$ & imp. amb. \\
\hline G. J. & $56 \mathrm{y}$ & $\mathrm{m}$ & C4-5 & 2 weeks & neg. & neg. & 94 & neg. & neg. & $\begin{array}{l}\text { pneumonia, } \\
\text { myoc. inf., } \\
\text { pancreat. }\end{array}$ & $\begin{array}{l}\text { pain, no } \\
\text { def. }\end{array}$ & imp. amb. \\
\hline S. L.*** & $60 \mathrm{y}$ & $\mathrm{m}$ & $\mathrm{T} 2-8$ & 4 weeks & neg. & neg. & 38 & neg. & St. Aur. & neg. & $\begin{array}{l}\text { moderate } \\
\text { deficit }\end{array}$ & imp. amb. \\
\hline B. E. & $75 \mathrm{y}$ & $\mathrm{f}$ & L3-4 & 4 weeks & neg. & neg. & 20 & neg. & neg. & neg. & $\begin{array}{l}\text { moderate } \\
\text { deficit }\end{array}$ & imp. amb. \\
\hline D. S. & $1 \mathrm{~m}$ & $\mathrm{~m}$ & C6-T2 & 2 weeks & neg. & neg. & $?$ & neg. & neg. & neg. & $\begin{array}{l}\text { severe } \\
\text { deficit }\end{array}$ & not amb. \\
\hline P. G. & $61 \mathrm{y}$ & $\mathrm{m}$ & C5-7 & 4 weeks & neg. & neg. & 54 & neg. & neg. & ank. spond. & $\begin{array}{l}\text { severe } \\
\text { deficit }\end{array}$ & not amb. \\
\hline \multicolumn{13}{|l|}{ Abscess } \\
\hline S. A. & $69 \mathrm{y}$ & f & L5-S1 & 6 weeks & neg. & neg. & 62 & neg. & neg. & $\begin{array}{l}\text { diabetes, } \\
\text { deep venous } \\
\text { thrombosis }\end{array}$ & $\begin{array}{l}\text { severe } \\
\text { deficit }\end{array}$ & imp. amb. \\
\hline Z. H. & $58 \mathrm{y}$ & $\mathrm{m}$ & L4-5 & 32 weeks & neg. & neg. & 70 & + & E. coli & myoc. inf. & $\begin{array}{l}\text { mild } \\
\text { deficit }\end{array}$ & not. amb. \\
\hline K. E. & $27 \mathrm{y}$ & $\mathrm{m}$ & T3-6 & 4 weeks & + & neg. & 40 & neg. & neg. & neg. & $\begin{array}{l}\text { severe } \\
\text { deficit }\end{array}$ & imp. amb. \\
\hline B. W. & $60 \mathrm{y}$ & $\mathrm{m}$ & L3-4 & 2 weeks & + & + & 55 & neg. & St. Aur. & neg. & $\begin{array}{l}\text { severe } \\
\text { deficit }\end{array}$ & imp. amb. \\
\hline P. R. & $67 \mathrm{y}$ & $\mathrm{f}$ & C4-5 & 2 weeks & neg. & neg. & $?$ & + & Ps. Aer. & neg. & plegia & not amb. \\
\hline B. H.** & $64 \mathrm{y}$ & $\mathrm{m}$ & C4-T8 & 1 week & + & + & 120 & neg. & neg. & $\begin{array}{l}\text { diabetes, } \\
\text { alcohol, } \\
\text { GI-ulcus }\end{array}$ & $\begin{array}{l}\text { severe } \\
\text { deficit }\end{array}$ & not amb. \\
\hline B. L. & $74 \mathrm{y}$ & f & $\mathrm{C} 1-\mathrm{T} 2$ & 2 weeks & + & + & 96 & neg. & neg. & neg. & $\begin{array}{l}\text { severe } \\
\text { deficit }\end{array}$ & not amb. \\
\hline K. G. & $51 \mathrm{y}$ & $\mathrm{m}$ & C6-7 & 4 weeks & neg. & neg. & 68 & neg. & Strept. & pulm. emb. & plegia & died \\
\hline L. A. & $26 \mathrm{y}$ & $\mathrm{m}$ & L3-5 & 1 week & neg. & + & 94 & + & $\begin{array}{l}\text { E. coli } \\
\text { Pr. Mir. }\end{array}$ & Crohn's dis. & $\begin{array}{l}\text { severe } \\
\text { deficit }\end{array}$ & died \\
\hline R. G.* & $65 \mathrm{y}$ & $\mathrm{m}$ & T12-L1 & 24 weeks & + & + & 88 & + & $\begin{array}{l}\text { St. Aur. } \\
\text { E. coli }\end{array}$ & $\begin{array}{l}\text { alcohol, } \\
\text { mult. myel. }\end{array}$ & plegia & died \\
\hline S. A.* & $67 \mathrm{y}$ & $\mathrm{m}$ & C4-7 & 2 weeks & + & + & 116 & + & St. Aur. & $\begin{array}{l}\text { nephritis, } \\
\text { alcohol }\end{array}$ & $\begin{array}{l}\text { severe } \\
\text { deficit }\end{array}$ & died \\
\hline S.W. & $74 \mathrm{y}$ & $\mathrm{m}$ & C3-6 & 2 weeks & + & + & 85 & neg. & St. Aur. & $\begin{array}{l}\text { alcohol, } \\
\text { cancer } \\
\text { PDA-Cath }\end{array}$ & $\begin{array}{l}\text { severe } \\
\text { deficit }\end{array}$ & imp. amb. \\
\hline Z.I. & $71 \mathrm{y}$ & f & L1-2 & 12 weeks & - & - & 125 & neg. & E. coli & neg. & $\begin{array}{l}\text { severe } \\
\text { deficit }\end{array}$ & not amb. \\
\hline E.E & $54 \mathrm{y}$ & $\mathrm{m}$ & C5-7 & 8 weeks & + & + & 45 & + & St. Aur. & $\begin{array}{l}\text { diabetes, } \\
\text { nephritis }\end{array}$ & $\begin{array}{l}\text { moderate } \\
\text { deficit }\end{array}$ & imp. amb. \\
\hline
\end{tabular}

Abbreviations: $\mathrm{ESR}=$ erythrocyte sedimentation rate of first hour; Bact. = bacteriology; Preop. Status=preoperative neurological status; $\mathrm{m}=$ male; $\mathrm{f}=$ female; neg.= negative; ?= not known; imp. amb.=postoperative improvement, independent ambulation; not $\mathrm{amb} .=$ no postoperative improvement, dependent on assistance; St. Aur. $=$ Staph. aureus; Ps. Aer. $=$ Ps. aeruginosa; Strept. $=$ Streptococci; Pr. Mir. $=$ Pr. mirabilis; GI-Ulcer $=$ gastrointestinal ulcer; Pancreat. $=$ pancreatitis; Myoc. Inf. $=$ Pulm. Emb. = pulmonary embolism; Crohn's Dis. =Crohn's disease; Mult. Myel. = multiple myeloma; PDACath. $=$ peridural catheter; $*=$ not operated; $* *=$ patient underwent two surgeries within 5 days; $* * *=$ patient underwent four operations within 3 years for recurrent granulomas 
Six patients had undergone conservative treatment with antibiotics first and were only transferred to our department after neurological deterioration had occurred.

Systemic signs of infection, ie fever, leucocytosis, positive blood cultures, were detected more often in patients with abscesses compared to granulomas. Positive blood cultures were detected in six patients with abscesses only. Overall, only $43 \%$ showed signs of fever and 52\% demonstrated a leucocytosis, while every patient had an elevated erythrocyte sedimentation rate (ESR) on admission.

Patients with abscesses were in significantly poorer general health $(P<0.01)$ with a significantly lower Karnofsky score (Karnofsky scores on admission $36 \pm 15$ and $57 \pm 21$, respectively; $P<0.01$ ), more severe neurological deficits and presented risk factors, such as diabetes or alcoholism, more often when compared to patients with granulomas. However, from clinical data or imaging studies alone we were unable to determine pre-operatively whether a granuloma or an abscess was present. There was no statistical difference in terms of length of history or age between the two groups.

\section{Surgical treatment and intra-operative findings}

Two moribund patients with spinal abscesses and uncontrollable septicemia were not operated on and died within days of admission. The remainder were operated on immediately. Due to accompanying osteomyelitis or spondylodiscitis a ventral approach was chosen in seven instances. Four of these required immediate anterior fusion after removal of infectious material. One patient with a granuloma at $\mathrm{C} 2-\mathrm{C} 5$ was placed in a Halo for 4 weeks until fusion with iliac crest bone and plating was performed. One patient with affection of $\mathrm{C} 5-\mathrm{C} 7$ received a carbon fibre vertebral replacement. Two patients underwent conventional ventral fusion with iliac crest bone and plating with the primary procedure. For the remaining three patients no fusion was required and immobilization of the cervical spine with a collar was sufficient. The remaining 17 operations were performed via a posterior approach without stabilization.

The wound was closed primarily with either epidural suction (18 operations) or suction/irrigation systems (six operations).

Staphylococcus aureus was the organism most commonly isolated. The remaining organisms isolated were E. coli, Pseudomonas aeruginosa, Proteus mirabilis, and hemolytic streptococci. For nine patients, no organism could be identified (Table 2). The histological diagnosis was either abscess or unspecific granulomatous inflammation.

\section{Complications}

Four surgical revisions were required due to postoperative recollection of inflammatory material in the wound: two after conventional epidural suction drains and two after suction/irrigation systems. In one case, conventional suction was changed to suction/irrigation and the wound closed once again. For the remaining cases, the wound was left open to heal secondarily.

\section{Outcome}

Two moribund patients with spinal abscesses were not operated on and died from uncontrollable septicemia even though the organism had been identified and antibiotic treatment installed accordingly. Of operated patients with abscesses, two patients died within 30 days despite specific antibiotic treatment after resistance testing. Of the remaining ten patients, five sustained significant neurological deficits postoperatively requiring assistance for their daily activities, while five patients made an incomplete recovery to ambulate independently.

The outcome for patients with granulomas was considerably better. There was no mortality in this group and six of eight patients improved postoperatively to a self-ambulatory status or kept their good pre-operative neurological status.

Overall, significant postoperative improvements were observed for sensory deficits, motor weakness, pain, and the Karnofsky score. On average, significant improvements were observed for patients with abscesses after 3 months for sensory deficits and pain, with only slight improvements for motor weakness, gait ataxia, and sphincter function. The Karnofsky score was left unchanged. For patients with granulomas, slight improvement was observed for sensory deficits, motor weakness, and pain, whereas the Karnofsky score improved significantly (Table 3).

Multiple regression analysis showed that a poor Karnofsky score, a low general health score, and an abscess as opposed to a granuloma were the only independent factors predicting high mortality. Patient age, length of history and severity of pre-operative neurological deficits did not show a significant influence on survival.

\section{Discussion}

A rising incidence of spinal epidural abscesses has been observed in recent years. ${ }^{7-10}$ Several explanations were offered, such as AIDS or intravenous drug abuse ${ }^{9,10}$ or the increasing number of elderly people. ${ }^{7-9}$ Intravenous drug abuse was thought to account for the high number of cervical abscesses as compared to series reported earlier this century. However, even though cervical infections predominate in our series, none of the patients had evidence of HIV infection or used intravenous drugs. The age distribution in our series does not suggest that spinal infections are restricted to elderly people. This leaves the increased incidence and the predominance of cervical abscesses unexplained. 
Table 3 Clinical course for patients with spinal inflammatory processes

\begin{tabular}{|c|c|c|c|c|}
\hline Group & $\mathrm{n}$ & Preop. & Postop. & 3 months \\
\hline \multicolumn{5}{|c|}{ Sensory function } \\
\hline Abscess & 4 & $1.5 \pm 1.9$ & $1.8 \pm 1.7$ & $2.5 \pm 2.1 *$ \\
\hline Granuloma & 7 & $4.1 \pm 0.9$ & $4.4 \pm 1.0$ & $4.3 \pm 1.3$ \\
\hline Total & 11 & $3.2 \pm 1.8$ & $3.5 \pm 1.8$ & $3.6 \pm 1.7 *$ \\
\hline \multicolumn{5}{|l|}{ Dysesthesias } \\
\hline Abscess & 4 & $4.8 \pm 0.5$ & $4.8 \pm 0.5$ & $4.8 \pm 0.5$ \\
\hline Granuloma & 7 & $4.7 \pm 0.8$ & $4.6 \pm 0.8$ & $4.3 \pm 1.0$ \\
\hline Total & 11 & $4.7 \pm 0.6$ & $4.6 \pm 0.7$ & $4.5 \pm 0.8$ \\
\hline \multicolumn{5}{|l|}{ Pain } \\
\hline Abscess & 4 & $3.3 \pm 0.5$ & $4.0 \pm 0.0$ & $4.3 \pm 0.5^{*}$ \\
\hline Granuloma & 7 & $3.6 \pm 1.1$ & $4.3 \pm 0.5$ & $4.4 \pm 0.8$ \\
\hline Total & 11 & $3.5 \pm 0.9$ & $4.2 \pm 0.4$ & $4.4 \pm 0.7 * *$ \\
\hline \multicolumn{5}{|c|}{ Motor weakness } \\
\hline Abscess & 4 & $1.0 \pm 1.4$ & $1.0 \pm 1.4$ & $1.5 \pm 1.9$ \\
\hline Granuloma & 7 & $3.9 \pm 1.1$ & $4.3 \pm 0.9$ & $4.4 \pm 0.8$ \\
\hline Total & 11 & $2.8 \pm 1.8$ & $3.1 \pm 1.9$ & $3.4 \pm 1.9 *$ \\
\hline \multicolumn{5}{|l|}{ Gait ataxia } \\
\hline Abscess & 4 & $1.3 \pm 1.9$ & $1.3 \pm 1.9$ & $1.5 \pm 2.4$ \\
\hline Granuloma & 7 & $3.6 \pm 1.4$ & $3.7 \pm 1.3$ & $3.7 \pm 1.5$ \\
\hline Total & 11 & $2.7 \pm 1.9$ & $2.8 \pm 1.9$ & $2.9 \pm 2.1$ \\
\hline \multicolumn{5}{|c|}{ Bladder function } \\
\hline Abscess & 4 & $1.8 \pm 2.4$ & $1.8 \pm 2.4$ & $2.0 \pm 2.4$ \\
\hline Granuloma & 7 & $4.4 \pm 1.0$ & $4.6 \pm 1.0$ & $4.6 \pm 1.1$ \\
\hline Total & 11 & $3.5 \pm 2.0$ & $3.5 \pm 2.1$ & $3.6 \pm 2.1$ \\
\hline \multicolumn{5}{|c|}{ Bowel function } \\
\hline Abscess & 4 & $1.8 \pm 2.4$ & $1.8 \pm 2.4$ & $2.0 \pm 2.4$ \\
\hline Granuloma & 7 & $4.6 \pm 0.8$ & $4.7 \pm 0.8$ & $4.7 \pm 0.8$ \\
\hline Total & 11 & $3.4 \pm 2.1$ & $3.5 \pm 2.1$ & $3.6 \pm 2.1$ \\
\hline \multicolumn{5}{|c|}{ Karnofsky score } \\
\hline Abscess & 4 & $38 \pm 15$ & $35 \pm 17$ & $38 \pm 24$ \\
\hline Granuloma & 7 & $57 \pm 19$ & $68 \pm 22$ & $72 \pm 24 * *$ \\
\hline Total & 11 & $49 \pm 19$ & $55 \pm 26$ & $58 \pm 29 *$ \\
\hline
\end{tabular}

Abbreviations: Preop., Postop. $=$ preoperatively and postoperatively, respectively; $*, * *=$ significant difference between pre-operative score and score after 3 months $(P<0.05$ and $P<0.01$, respectively; $t$-test for paired variables $)$

\section{Surgery or antibiotics?}

The advent of antibiotics has changed the outcome of patients with this life threatening disease significantly. ${ }^{4}$ However, since antibiotics have become available further significant improvements in mortality rates have not been reported within the last decades. Mortality dropped from $37 \%{ }^{4}$ and $88 \%{ }^{5}$ in the preantibiotic area to values of $17 \%{ }^{4}$ or $14 \% .^{7}$ In selected series, mortality rates of as low as $5 \%$ have been reported $^{10,14}$ but do not represent an unselected series of patients.

Several publications have questioned the role of surgery suggesting that a considerable number of patients may be treated by antibiotics alone..$^{15,16}$ Others have cautioned against this policy emphasizing the need for early surgical treatment. ${ }^{7-9}$

We consider an epidural infection an emergency calling for immediate surgical intervention as soon as the patient has developed even minor neurological deficits. ${ }^{8,17,18}$ A perfectly normal patient with just an elevated ESR and local pain may progress to complete paraplegia in as little as $2 \mathrm{~h} .{ }^{19}$ Our experience suggests that treatment should be started before severe neurological deficits have developed. Chances for significant neurological improvement or maintaining a neurologically intact status may decline rapidly if surgery is not performed at the earliest possible time. ${ }^{7,9}$

The classical triad of local pain, fever and a neurological deficit describes the clinical picture for most patients adequately. If risk factors such as diabetes, recent trauma, alcoholism, cancer, old age etc. are present, these signs should lead to immediate clinical and radiological studies.

\section{Imaging}

MRI has become the preferred imaging modality to demonstrate the extent of the inflammatory process. $^{8,20,21}$ However, radiological studies such as MRI may underestimate the severity of cord compression considerably. ${ }^{14,22}$ Quite often the neurological picture seems not to be adequately explained by what looks like a small enhancing lesion on MRI. It is important to emphasize that the severity of neurological symptoms and potential cord damage does not correlate to the amount of visible compression. ${ }^{18,23}$ Other factors, such as vascular compromise and spinal venous thrombosis are believed to contribute significantly. ${ }^{2,3,19}$ Conventional myelography may still give a more adequate assessment in terms of the severity of cord compression in this entity, ${ }^{7,14,22}$ especially if multiple spinal levels are involved. According to our experience, it is not possible to differentiate between epidural granulomas and abscesses on MRI or any other radiographic study.

\section{Systemic parameters of infection}

Among the systemic parameters used to document infection-fever, leucocytosis, and elevation of the erythrocyte sedimentation rate (ESR)-several authors reported that only an elevated ESR was a consistent finding in cases of epidural spinal infections and in fact a good parameter for postoperative follow up. ${ }^{7,9,10,17,22}$ Repeated postoperative ESR measurements and measurements of $\mathrm{C}$ reactive protein (CRP) may indicate successful treatment or alert the physician to a new or not sufficiently treated infectious problem.

\section{Surgical treatment}

The surgical approach is determined by the extent of bony and spinal cord involvement. Inflammatory processes located anteriorly of the cord are almost exclusively found in cases of osteomyelitis or spondylodiscitis. ${ }^{8}$ A posterior approach might give enough exposure of the intraspinal part. However, the 
underlying infection inside the vertebral body or disc space cannot be treated appropriately. Therefore, we recommend an anterior approach in such cases to achieve adequate debridement of the affected bone together with removal of the intraspinal part. If required, fusion can be achieved in the primary operation. On the other hand, if the inflammatory process does not involve intervertebral discs or vertebral bodies a posterior approach will be sufficient.

In one case of a cervical granuloma we were hesitant to proceed to spinal fusion after extensive bony resection and debridement during the same operation. We immobilized the cervical spine in a Halo, and performed bone grafting and fusion in a second operation after 4 weeks with an excellent clinical result. Another patient required fusion due to postoperative instability, while one patient received a carbon fibre transplant after resection of C6 during the same operation. Even though no problems arose with this transplant in this particular patient we generally prefer iliac crest bone over an inert material. Several studies suggest that bone grafting and fusion can be undertaken primarily without the danger of a relapse or breakdown of the bone graft. ${ }^{3,9,24-27}$

In terms of wound management, several policies have been advocated: primary closure with epidural drains, primary closure with suction/irrigation systems or secondary closure. From our point of view no general recommendation can be given. In patients with good general health, primary wound closure has not caused any problems in terms of wound infection or recollection of putrid material epidurally. ${ }^{9,18,28,29}$ For patients in poor health, we have closed the wound primarily in a number of cases but had to revise the wound again in four instances. In these cases, we have then left the wound open in three patients to heal by secondary intent. ${ }^{18}$ For one patient, a conventional suction drain was changed to a suction/irrigation system with closure of the wound and a very satisfactory result. ${ }^{19,28,30,31}$ Lange et al $^{31}$ claimed significantly better survival rates and neurological outcome in patients treated with suction/irrigation systems compared to conventional drainage systems. We were unable to substantiate such a difference in outcome.

\section{Postoperative outcome}

Postoperative neurological outcome is almost directly related to pre-operative neurological status. ${ }^{4,7-10,14,17}$ Once severe paralysis or even complete paraplegia have set in the chances for neurological recovery are greatly reduced, especially in patients with generalized septicemia, other medical diseases, or old age. This is emphasized by the better postoperative results obtained for patients with epidural granulomas as compared to epidural abscesses. ${ }^{1,32}$ In general, symptoms develop slower and progress to a less severe degree in the former group putting them in a better pre-operative position. ${ }^{7}$ Therefore, we strongly recommend operation in all patients fit for surgery, before neurological deficits develop. If conservative treatment does not control the inflammation and the patient deteriorates neurologically, the chances for recovery are greatly reduced. ${ }^{8}$

Even though survival rates have undoubtedly improved there is still a high mortality of up to $23 \%{ }^{8}$ or $38 \%$ for cervical abscesses. ${ }^{29}$ If the inflammatory process is localized-as in osteomyelitis-and the infection has developed by local spread and/or the process has proceeded to a granulomatous lesion the survival prognosis is excellent. However, in patients with poor general health, septicemia, and putrid material in the spinal canal it is the systemic rather than the local inflammatory disease which endangers life and survival will mainly depend on successful treatment of the systemic infection.

A patient with a spontaneous epidural infectious process should undergo MRI scanning to determine the exact extension of the inflammatory process. Additionally, CT and myelography may be employed. Every attempt should be made to isolate the underlying organism - either locally or systemically - so that specific antibiotic treatment can be installed.

Surgical treatment is indicated before severe neurological deficits occur or the patient's health deteriorates. Once an advanced stage of the disease is reached mortality remains high and survivors are likely to sustain severe neurological deficits. With surgical intervention at an early state the overall prognosis is favorable.

\section{References}

1 Browder J, Meyers R. Pyogenic infections of the spinal epidural space. A consideration of the anatomic and physiologic pathology. Surgery 1941; 10: $296-308$.

2 Dandy W. Abscesses and inflammatory tumors in the spinal epidural space (so-called pachymeningitis externa). Arch Surg 1926; 13: 477 - 494.

3 Eismont FJ, Montero C. Infections of the spine In: Davidoff RA (ed.) Handbook of the Spinal Cord. Volume 5. New York: Mariel Dekker; 1987 pp $411-449$

4 Heusner AP. Nontuberculous spinal epidural infections. $N$ Engl J Med 1948; 239: $845-854$.

5 Schmalz A. Über akute Pachymeningitis spinalis externa. Virch Arch 1925; 257: 521 - 560.

6 Weber W. Über spinale epidurale Eiterungen und ihre Komplikationen (Rückenmarksabszess). Zentralbl Neurochir 1955; 15: $226-232$.

7 Danner RL, Hartman BJ. Update of spinal epidural abscess: 35 cases and review of the literature. Rev Infect Dis 1987; 9: 265274.

8 Hlavin ML, Kaminski HJ, Ross JS, Ganz E. Spinal epidural abscess: a ten year perspective. Neurosurgery 1990; 27: 177-184.

9 Martin RJ, Yuan HA. Neurosurgical care of spinal epidural, subdural, and intramedullary abscesses and arachnoiditis. Orthop Clin N Am 1996; 27: 125-136.

10 Nussbaum ES et al. Spinal epidural abscess: a report of 40 cases and review. Surg Neurol 1992; 38: 225-231.

11 Karnofsky DA, Burchenal JH. The clinical evaluation of chemotherapeutic agents in cancer. In: MacLeod CM (ed.) Evaluation of Chemotherapeutic Agents. New York: Columbia University Press; 1949, pp 191-205. 
12 Klekamp J, Samii M. Introduction of a score system for the clinical evaluation of patients with spinal processes. Acta Neurochir 1993; 123: 221 - 223.

13 Kaplan EL, Meier P. Nonparametric estimation from incomplete observations. J Am Sat Assoc 1958; 53: $457-481$.

14 Darouiche RO. Bacterial spinal epidural abscess. Review of 43 cases and literatre survey. Medicine 1992; 71: 369-385.

15 Garcia A, Grantham SA. Hematogenous pyogenic vertebral oseomyelitis. J Bone Joint Surg 1960; 42A: 429-436.

16 Leys D et al. Decreased morbidity from acute bacterial spinal epidural abscess using computed tomography and nonsurgical treatment in selected patients. Ann Neurol 1985; 17: 350-355.

17 Liem LK et al. Thoracic epidural abscess. J Spinal Disord 1994; 7: $449-454$

18 Verner EF, Musher DM. Spinal epidural abscess. Med Clin N Am 1985; 69: 375 - 384

19 Philipps GE, Jefferson A. Acute spinal epidural abscess. Observations from fourteen cases. Post Grad Med J 1979; 55: $712-715$.

20 Rigamonti D et al. Epidural abscess in the cervical spine. $M t$ Sinai J Med 1994; 61: $357-362$.

21 Sadato $\mathrm{N}$ et al. Spinal epidural abscess with gadoliniumenhanced MRI: serial follow-up studies and clinical correlations. Neuroradiology 1994; 36: $44-48$.

22 Curling Jr OD, Gower DJ, McWorther JM. Changing concepts in spinal epidural abscess: a report of 29 cases. Neurosurgery 1990; 27: $185-192$.
23 Baker AS, Ojemann RG, Swartz MN, Richardson EP. Spinal epidural abscess. $N$ Engl J Med 1975; 293: $463-468$.

24 Collert S. Osteomyelitis of the spine. Acta Orthop Scand 1977; 48: $283-290$

25 Fellaender M. Paraplegia in spondylitis, results of operative treatment. Paraplegia 1975; 13: $75-88$.

26 Gepstein R et al. Management of pyogenic vertebral osteomyelitis with spinal cord compression in the elderly. Paraplegia 1992 30: $795-798$.

27 Kiraldy WH, Thomas G. Anterior approaches in the diagnosis and treatment of infections of the vertebral bodies. $J$ Bone Joint Surg 1975; 47A: $87-110$

28 Gleber BR, Pierson EW, Birkmann LW. Spinal epidural abscess. Nebr Med J 1981; 66: 10-14.

29 Zeidman SM, Rhines L, Sampath P, Rigamonti D. Spinal epidural abscess. Contemp Neurosurg 1995; 17: $1-5$.

30 Garrido E, Rosenwasser RH. Experience with the suctionirrigation technique in the management of spinal epidural infection. Neurosurgery 1983; 12: 678-679.

31 Lange $\mathrm{M}$ et al. Diagnosis and results of different treatment regimens in patients with spinal abscesses. Acta Neurochir 1993 125: $105-114$

32 Ravicovitch MA, Spallone A. Spinal epidural abscesses. Surgical and parasurgical management. Eur Neurol 1982; 21: 347 - 357. 